PNL-7213

UC-602

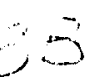

\title{
A Review of the Environmental Behavior of Uranium Derived From Depleted Uranium Alloy Penetrators
}
R. L. Erikson
J. R. Divine
C. J. Hostetler
K. R. Price

January 1990

Prepared for

U.S. Army Combat Systems Test Activity

Aberdeen Proving Ground, Aberdeen, Maryland under a Related Services Agreement with the U.S. Department of Energy Contract DE-AC06-76RLO 1830

Pacific Northwest Laboratory

Operated for the U.S. Department of Energy

by Battelle Memorial Institute 


\title{
DISCLAIMER
}

This report was prepared as an account of work sponsored by an agency of the United States Government. Neither the United States Government nor any agency thereof, nor Battelle Memorial Institute, nor any of their employees, makes any warranty, expressed or implied, or assumes any legal liability or responsibility for the accuracy, completeness, or usefulness of any information, apparatus, product, or process disclosed, or represents that its use would not infringe privately owned rights. Reference herein to any specific commercial product, process, or service by trade name, trademark, manufacturer, or otherwise, does not necessarily constitute or imply its endorsement, recommendation, or favoring by the United States Government of any agency thereof, or Battelle Memorial Institute. The views and opinions of authors expressed herein do not necessarily state or reflect those of the United States Government or any agency thereof.

\author{
PACIFIC NORTHWEST LABORATORY \\ operated by \\ BATTELLE MEMORIAL INSTITUTE \\ for the \\ UNITED STATES DEPARTMENT OF ENERGY \\ under Contract DE-ACO6-76RLO 1830
}

Printed in the United States of America

Available to DOE and DOE contractors from the

Office of Scientific and Technical Information, P.O. Box 62, Oak Ridge, TN 37831; prices available from (615) 576-8401. FTS 626-8401.

Available to the public from the National Technical Information Service, U.S. Department of Commerce, 5285 Port Royal Rd., Springfield, VA 22161.

NTIS Price Codes, Microfiche A01

Printed Copy

\begin{tabular}{cr}
\hline Price Code & Page Range \\
\hline A02 & $1-10$ \\
A03 & $11-50$ \\
A04 & $51-75$ \\
A05 & $76-100$ \\
A06 & $101-125$ \\
A07 & $126-150$ \\
A08 & $151-175$ \\
A09 & $176-200$ \\
A10 & $201-225$ \\
A11 & $226-250$ \\
A12 & $251-275$ \\
A13 & $276-300$ \\
A14 & $301-325$
\end{tabular}

\begin{tabular}{cc}
\hline Price Code & Page Range \\
\hline A15 & $326-350$ \\
A16 & $351-375$ \\
A17 & $376-400$ \\
A18 & $401-425$ \\
A19 & $426-450$ \\
A20 & $451-475$ \\
A21 & $476-500$ \\
A22 & $501-525$ \\
A23 & $526-550$ \\
A24 & $551-575$ \\
A25 & $576-600$ \\
A99 & $601-U p$
\end{tabular}



R. L. Erikson
C. J. Hostetler
J. R. Divine
K. R. Price

January 1990

Prepared for U.S. Army Combat Systems Test Activity Aberdeen Proving Ground, Aberdeen, Maryland under a Related Services Agreement with the U.S. Department of Energy

Contract DE-ACO6-76RLO 1830

Pacific Northwest Laboratory

Richland, Washington 99352 


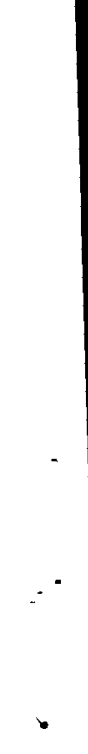




\section{SUMMARY}

The use of depleted uranium (DU) penetrators as armor-piercing projectiles in the field results in the release of uranium into the environment. Elevated levels of uranium in the environment are of concern because of radioactivity and chemical toxicity. In addition to the direct contamination of the soil with uranium, the penetrators will also chemically react with rainwater and surface water. Uranium may be oxidized and leached into surface water or groundwater and may subsequently be transported. In this report, we review some of the factors affecting the oxidation of the DU metal and the factors influencing the leaching and mobility of uranium through surface water and groundwater pathways, and the uptake of uranium by plants growing in contaminated soils.

The uranium in the DU penetrators is in the form of uranium metal alloyed with $0.75 \mathrm{wt} \% \mathrm{Ti}$ to reduce the overall corrosion rate and to improve mechanical properties of the penetrator. Because uranium metal is thermodynamically unstable relative to more oxidized forms of uranium [U(IV) and $U(V I)]$, it will react to form oxides when in contact with the earth's atmosphere. The primary oxidation products are hyperstoichiometric U(IV) oxides of the form $\mathrm{UO}_{2+\mathrm{x}}$, where $0<x<0.4$. Further oxidation to mixed $U(\mathrm{IV})$ and $U(V I)$ oxides and to $U(V I)$ oxides may also occur. A review of reaction rates suggest that the most rapid atmospheric oxidation of uranium metal occurs in contact with pure water vapor. The oxidation rates of uranium metal are much slower in dry air, $\mathrm{CO}_{2}$, and $\mathrm{O}_{2}$ and water vapor. Under some conditions, the addition of $0.75 \% \mathrm{Ti}$ to uranium metal appears to slow the oxidation rate by a factor of approximately 16. Corrosion rates for uranium metal under aqueous conditions, such as might exist in surface-water pools, tend to be higher than atmospheric oxidation rates.

The potential for the migration of uranium depends on the chemistry of local soils and pore waters as well as on the oxidation products of the DU penetrator. The mobility of dissolved uranium will depend on the Eh, $\mathrm{pH}$, and the presence of complexing ligands in local groundwaters. Uranium (VI) is more mobile than $U$ (IV) because of aqueous complexation reactions involving ligands commonly found in natural waters; carbonate and phosphate are 
considered the most important of these. The transport of dissolved uranium can also be affected by attenuation reactions that can reduce uranium concentrations in groundwater and surface waters. These reactions include ion exchange and specific adsorption of uranium on organic matter, clay minerals, and ferric oxides and oxyhydroxides commonly present in soils.

An evaluation of the potential for the migration and uptake of uranium from DU penetrators at a particular site requires detailed field characterization data for the chemical composition of the surface water, groundwater, and soil. Measurements for surface and pore waters should be made that include $\mathrm{pH}$, Eh, and the concentrations of major cations, anions, selected trace metals, and organic compounds. In addition, the soils should be characterized for mineral type and content and for organic matter. 


\section{ACKNOWLEDGMENTS}

The authors would like to acknowledge Laurel $K$. Grove for editorial assistance and R. Jeff Serne for the technical review of this document. We especially would like to acknowledge the consideration of Pergemon Press, Dr. Donald Langmuir, and Dr. Ching-Kuo Daniel Hsi for their permission to reprint the figures used in this report. Al1 figures were reprinted with permission from [Geochimica et Cosmochimica Acta, 42, Langmuir, D., "Uranium Solution-Mineral Equilibria at Low Temperatures With Application to Sedimentary Ore Deposits", 1978, Pergamon Press] and [Geochimica et Cosmoschimica Acta, 49, Hsi, C-K. D. and D. Langmuir, "Adsorption of Uranyl onto Ferric 0xyhydroxides: Application of the Surface Complexation SiteBinding Mode1", 1985, Pergamon Press]. 
. 


\section{CONTENTS}

SUMMARY

ACKNOWLEDGMENTS ...................... . . . . v v INTRODUCTION . . . . . . . . . . . . . . . . . . 1

PAST STUDIES . . . . . . . . . . . . . . . . . . 2

OXIDATION OF URANIUM AND DU $-0.75 \%$ TI ALLOY . . . . . . . . . 3

Atmospheric oxidation ................... 6

Aqueous Corrosion ................... . . . 7

FACTORS AFFECTING SOURCE-TERM URANIUM CONCENTRATIONS . . . . . . . 9

ATTENUATION BEHAVIOR OF URANIUM. . . . . . . . . . . . . . 16

UPTAKE OF URANIUM BY PLANTS. . . . . . . . . . . . . . . . 21

CONCLUSIONS. . . . . . . . . . . . . . . . . . 22

REFERENCES ........................... 23 


\section{FIGURES}

1 Distribution of the significant U(IV) complexes as a

function of $\mathrm{pH}$ at $25^{\circ} \mathrm{C}$ calculated for the ligand

concentrations shown ................

2 The solubility of uraninite $\left(\mathrm{UO}_{2}\right)$ as a function of $\mathrm{pH}$ at $25^{\circ} \mathrm{C}$, showing the effect of dissolved fluoride ......

3 Distribution of significant $U(V I)$ complexes at $25^{\circ} \mathrm{C}$ as a function of $\mathrm{pH}$ for a groundwater having the following composition: $\mathrm{pCO}_{2}=10^{-2.5} \mathrm{~atm}, \mathrm{~F}=0.3 \mathrm{ppm}, \mathrm{Cl}=10 \mathrm{ppm}$,

$\mathrm{SO}_{4}=100 \mathrm{ppm}, \mathrm{PO}_{4}=0.1 \mathrm{ppm}, \mathrm{SiO}_{2}=30 \mathrm{ppm} \ldots \ldots$

4 Eh-pH diagram in the system $\mathrm{U}-\mathrm{O}_{2}-\mathrm{CO}_{2}-\mathrm{H}_{2} \mathrm{O}$ at $25^{\circ} \mathrm{C}$, showing the stability field of $\mathrm{UO}_{2}$ for a total $\mathrm{U}$

concentration of $0.24 \mathrm{ppm}$ and $\mathrm{a} \mathrm{pCO} 2$ of $0.01 \mathrm{~atm}$......

5 The solubility of $\mathrm{UO}_{2}$ at $25^{\circ} \mathrm{C}$ and $\mathrm{pH} 8$ as a function of $\mathrm{Eh}$ and $\mathrm{pCO}_{2} \ldots \ldots \ldots$

6 The solubility of $\mathrm{UO}_{2}$ at $\mathrm{pH} 6, \mathrm{pCO}_{2}=0.01 \mathrm{~atm}$, and $25^{\circ} \mathrm{C}$ for two phosphate concentrations ..........

7 The solubility of carnotite at $25^{\circ} \mathrm{C}$ as a function of $\mathrm{pH}$ and $\mathrm{pCO}_{2}$ for concentrations of $\mathrm{K}=39 \mathrm{ppm}$ and $\mathrm{VO}_{4}=0.1 \mathrm{ppm} \ldots$.

8 The solubility of tyuyamunite at $25^{\circ} \mathrm{C}$ as a function of $\mathrm{pH}$ and $\mathrm{pCO}_{2}$ for concentrations of $\mathrm{Ca}=80 \mathrm{ppm}$ and $\mathrm{VO}_{4}=0.1 \mathrm{ppm}$..

9 The solubility of autunite at $25^{\circ} \mathrm{C}$ as a function of $\mathrm{pH}$ and $\mathrm{pCO}_{2}$ for concentrations of $\mathrm{Ca}=80 \mathrm{ppm}$ and $\mathrm{PO}_{4}=0.1 \mathrm{ppm} \ldots$.

10 Adsorption of uranyl ion versus $\mathrm{pH}$ at a total $U$ concentration of $10^{-5} \mathrm{~mol}$ ar $(2.4 \mathrm{ppm})$ onto $1 \mathrm{~g} / \mathrm{L}$ suspensions of ferric oxyhydroxides in $0.1 \mathrm{M} \mathrm{NaNO}_{3}$ solutions at $25^{\circ} \mathrm{C} \ldots \ldots$

\section{TABLES}

1 Mass Loading of Spherical U Metal Particles . . . . . . . . 5

2 Atmospheric Oxidation Rates of U Metal . . . . . . . . . 6

3 Electrode Potentials for Metals (in V) at $29^{\circ} \mathrm{C} \ldots \ldots 8$ 


\section{INTRODUCTION}

The addition of heavy metals to armor-piercing penetrators makes the penetrators more effective because of the higher kinetic energies on impact. Moreover, using uranium metal in a penetrator provides an additional pyrophoric quality, making it more effective on the battlefield. Depleted uranium (DU), because of its availability and its reduced radioactivity compared to natural uranium, has been put to this use in ammunition manufacture. However, test firing of DU alloy (DU - $0.75 \% \mathrm{~T} i$ ) penetrators in the field may cause contamination because uranium is released into the environment. Small particles may be dispersed and deposited on soils as a result of the impact of the penetrator. Alternatively, if the penetrator does not impact a downrange target, it may come to rest relatively intact on or near the soil surface or in shallow surface water. In any case, not only will there be direct contamination of the soil with uranium, but the penetrators will also be subject to chemical interactions that are associated with weathering (i.e., dissolution) reactions involving rainwater or surface water.

Elevated levels of uranium $(U)$ in soil are of concern because of radioactivity and chemical toxicity (Hanson and Miera 1976; Loewenstein 1980). Uranium may be oxidized and leached into surface water or groundwater and may subsequently be transported. These processes could lead to direct exposure to humans who ingest the contaminated water. Potentially toxic groundwater concentrations could result from leaching of the DU, depending on the rate of leaching of $U$ by rainwater. In addition, $U$ could enter the food chain through plants growing in contaminated sediment or soil, animals consuming the contaminated vegetation, and humans then consuming either the contaminated vegetation or the contaminated animals. The potential dose from this exposure pathway would add to the dose from the direct ingestion exposure pathway. A final potential exposure pathway is from inhalation of contaminated soil particles. The relative importance of these exposure pathways will depend on the local environmental conditions.

In this report, we review some of the factors affecting conversion of the DU metal to oxide, factors influencing the leaching and mobility of $U$ 
through surface water and groundwater pathways, and the uptake of $U$ by $p l$ ants growing in contaminated soils. The concentration of dissolved $U$ entering the soil profile will be governed by the weathering reactions among the $U$ metal particles, their oxidation products, and water. Therefore, the chemical kinetics of reactions involving the transformation of the $U$ metal into $\mathrm{U}$-oxides or other weathering products and the relative solubilities of those products in soil pore waters must be evaluated. In addition, both the presence of complexing ligands and the redox conditions of the pore waters affect the quantity of $U$ leached from different $U$ solids. These effects must also be evaluated. Reactions between the dissolved $U$ and the minerals and mineral surfaces in the local soils may attenuate $U$ concentrations in the soil profile. Such reactions include precipitation of secondary minerals and adsorption reactions that can reduce the concentrations of $U$ in soil pore waters. In this review, three factors affecting the mobility of $U$ from spent penetrators are discussed: 1) the oxidation of $U$ and $D U$ alloy metal into more stable oxides, 2) the effects of the chemical composition of the soil pore waters involved in the weathering process, and 3 ) the attenuation of dissolved $U$ by local soils. Finally, we review the factors influencing the uptake of $U$ by $p l a n t s$ growing in contaminated soils.

\section{PAST STUDIES}

Several studies have measured $U$ contamination in soils and groundwater that was a result of impacts of DU penetrators at target ranges. For example, observations at a DU-explosive testing site at the Los Alamos Scientific Laboratory (LASL) have found $U$ concentrations in standing water in the detonation crater in the range of 87 to $280 \mathrm{ppm}$ (Hanson and Miera 1977). After a rainstorm, concentrations in runoff water 100 and $250 \mathrm{~m}$ from the site were 52 and $37 \mathrm{ppb} U$, respectively. Thus, migration of dissolved $U$ in surface water is an important factor in $U$ transport at the LASL site. Concentrations of $U$ in the soils at the LASL testing site were highest (average of $4500 \mathrm{ppm}$ ) in the uppermost $2.5 \mathrm{~cm}$ of soil at a distance of 0 to $10 \mathrm{~m}$ from the detonation point. The concentration of $U$ decreased to about $700 \mathrm{ppm}$ at a distance of 50 to $200 \mathrm{~m}$ from the detonation point. However, the $U$ had also 
penetrated the soil to depths of $30 \mathrm{~cm}$. A value of about $50 \mathrm{ppm} U$ in the soil is considered chemically toxic to plants (Hanson 1974).

Stoetzel et a1. (1983) have reported soil and surface water measurements of uranium concentrations for two target areas (the B-3 and Ford's Farm ranges) at the Aberdeen Proving Grounds in Maryland. Average concentrations of $U$ in the soils ranged from $1.3 \mathrm{ppm}$ at the $B-3$ range (open-air soft target range) and $3.6 \mathrm{ppm}$ at the Ford's Farm site (open-air hard target area). (a) These concentrations are only slightly higher than those in several U.S. soils in which the natural $U$ concentration is expected to be "normal, " that is, uranium concentrations in the range of 0.6 to $1.6 \mathrm{ppm}$ (Hanson and Miera 1976, 1977).

Water samples collected from the B-3 range and the Ford's Farm site contained $U$ concentrations between 0.03 and $43 \mathrm{ppb}$ and between 0.13 and $59 \mathrm{ppb}$, respectively. Typical river waters, contacting igneous rocks and clay, contain about $0.5 \mathrm{ppb}$, while waters in contact with carbonates can be higher. Normal maxima are around $0.2 \mathrm{ppm}$ (Hanson 1974). Thus the U concentrations at the Aberdeen Proving Ground are somewhat high. However, in general, the total $U$ concentrations in both the soil and local waters measured at the Aberdeen Proving Grounds are considerably less than the concentrations reported for the LASL site. Clearly, the variations in the environmental conditions at testing sites are reflected by the differences in mobility of dissolved DU. As will be discussed in the following sections, the mobility of DU in the environment is influenced by environmental conditions and complex processes, such as oxidation, aqueous complexation, precipitation, and adsorption.

\section{OXIDATION OF URANIUM AND DU $-0.75 \%$ Ti ALLOY}

The $U$ in the DU penetrators is in the form of $U$ metal alloyed with $0.75 \mathrm{wt} \% \mathrm{Ti}$ to reduce the overall corrosion rate and to improve mechanical properties of the penetrator. Because $U$ metal is thermodynamically unstable

(a) Open-air testing at Ford's Farm was discontinued in 1980, and subsequent test firing was conducted in an enclosure. A11 test firing of DU penetrators at Ford's Farm was discontinued in 1985. 
with respect to more oxidized forms of $U[U(I V)$ and $U(V I)]$, it will react to form them when in contact with the earth's atmosphere. The ability of water to dissolve $U$ depends on the oxidation state of the $U$.

Published work on the oxidation of $U$ metal has primarily focussed on oxidation at the relatively high temperatures found in reactor environments or in fires (approximately $100^{\circ} \mathrm{C}$ to $1,000^{\circ} \mathrm{C}$ ). However, some data are available for the oxidation of $U$ metal in contact with dry air, moist air, water vapor, and carbon dioxide at temperatures less than $100^{\circ} \mathrm{C}$ (Ritchie 1981; Tyzack and Cowen 1976). The primary oxidation products are hyperstoichiometric U(IV) oxides of the form $\mathrm{UO}_{2+x}$, where $0<x<0.4$. The oxidation reactions are:

$$
\begin{aligned}
U+[(2+x) / 2] \mathrm{O}_{2} & =U \mathrm{O}_{2+x} \\
U+(2+x) \mathrm{H}_{2} \mathrm{O} & =U \mathrm{O}_{2+\mathrm{x}}+(2+x) \mathrm{H}_{2} \\
U+2 \mathrm{CO}_{2} & =U \mathrm{OO}_{2}+2 \mathrm{CO}
\end{aligned}
$$

Further oxidation to mixed $U(I V)$ and $U(V I)$ oxides (e.g., $U_{4} 0_{9}, U_{3} 0_{7}$, and $\mathrm{U}_{3} \mathrm{O}_{8}$ ) and to $\mathrm{U}(\mathrm{VI})$ oxides $\left(\mathrm{UO}_{3} \cdot \mathrm{nH}_{2} \mathrm{O}\right)$ may also occur (Ritchie 1981; Bloch et al. 1982; Aronson et al. 1957).

Two limiting cases bound the rate of oxidation of the $U$ metal contained in a penetrator following a test firing: either 1) the $U$ metal oxidizes immediately and completely upon target impact, or 2) none of the $U$ metal oxidizes until it is on the ground. The first case most closely represents the impact of a penetrator on a hard target (such as at the Ford's Farm site). The second case most closely represents the landing of an intact penetrator, or large pieces of a penetrator, on the soil of a soft target range (such as at the B-3 range). The actual behavior (with oxidation occurring before and following deposition) depends on the details of the impact (whether with a target, other materials, or the ground), including the temperatures reached during impact and the size/frequency distribution of the dispersed particles. For the purposes of this review, we consider the 
bounding case in which oxidation does not occur until after impact or deposition onto the soil. Our calculations provide a lower estimate of the rate at which $U(I V)$ and $U(V I)$ become available for leaching into water.

The mass loading (amount of mass present in a particle per unit surface area) and the oxidation rate (mass oxidized per unit surface area per unit time) govern the rate at which $U$ metal is converted into $U(I V)$. The mass loading can be calculated from the size/frequency distribution of dispersed particles or pieces of a penetrator. In the absence of adequate information regarding size/frequency distributions, we provide trial calculations for $1 \mathrm{~kg}$ of $U$ metal divided into $N$ spheres of equal mass. The choice of spherical geometry is arbitrary and will affect the results of the calculation by only a factor of approximately 2. Uranium metal has a molecular weight of $238,029 \mathrm{mg} / \mathrm{mole}$, and a molar volume of $12.497 \mathrm{~cm}^{3} / \mathrm{mole}$ (Robie et al. 1978). Table 1 shows the mass (M), surface area (A), and mass loading (M/A) of each $U$ metal sphere.

Note that as the particle size decreases, the same amount of mass has more surface area. For example, the combined surface area of 1 million spheres each of $1 \mathrm{mg}$ mass and $0.00678 \mathrm{~cm}^{2}$ surface area is $6,780 \mathrm{~cm}^{2}$. Thus, for a given oxidation rate, greater amounts of $U$ metal will be oxidized per unit time as the average particle size becomes smaller. For example, hypothetical DU penetrators that are $5 / 8 \mathrm{in} .(1.59 \mathrm{~cm})$ in diameter and 14 in.

\section{TABLE 1. Mass Loading of Spherical U Metal Particles}

\begin{tabular}{|c|c|c|c|}
\hline $\mathrm{N}$ & Mass (mg) & Area $\left(\mathrm{cm}^{2}\right)$ & $M / A\left(\mathrm{mg} / \mathrm{cm}^{2}\right)$ \\
\hline 1 & $1,000,000$ & 67.6 & 14,800 \\
\hline 10 & 100,000 & 14.6 & 6,850 \\
\hline 100 & 10,000 & 3.15 & 3,180 \\
\hline 1,000 & 1,000 & 0.678 & 1,470 \\
\hline 10,000 & 100 & 0.146 & 685 \\
\hline 100,000 & 10 & 0.0315 & 318 \\
\hline $1,000,000$ & 1 & 0.00678 & 148 \\
\hline
\end{tabular}


(35.56 cm) long have a mass of $1,345,000 \mathrm{mg}$, a surface area of $181.6 \mathrm{~cm}^{2}$, and the surface loading ratio is $7406 \mathrm{mg} / \mathrm{cm}^{2}$.

\section{Atmospheric 0xidation}

Oxidation rates are given in units of milligrams of $U$ metal oxidized per square centimeter per hour $\left(\mathrm{mg} / \mathrm{cm}^{2}-\mathrm{h}\right)$. Table 2 lists oxidation rates for $U$ metal (Ritchie 1981) under various conditions. A review of reaction rates suggest that the most rapid oxidation of $U$ metal occurs when $U$ metal is in contact with pure water vapor (Ritchie 1981; Tyzack and Cowen 1976). At $25^{\circ} \mathrm{C}$, this rate is approximately $0.024 \mathrm{mg} \mathrm{U} / \mathrm{cm}^{2}-\mathrm{h}$. The oxidation rates are much slower in dry air (0.000026), $\mathrm{CO}_{2}(0.000001)$, and $\mathrm{O}_{2}$ and water vapor (0.00041). The reaction rates are exponential functions of temperature, approximately doubling as the temperature increases from $25^{\circ} \mathrm{C}$ to $35^{\circ} \mathrm{C}$. Note that in Table 2 we used the approximation that the rate law applies below $40^{\circ} \mathrm{C}$ to extrapolate rates for the oxidation of $U$ at $25^{\circ} \mathrm{C}$ in the $U$-dry air and $\mathrm{U}-\mathrm{O}_{2}$-water vapor systems. The oxidation rate of $\mathrm{U}-0.75 \% \mathrm{Ti}$ alloy has been measured at $74^{\circ} \mathrm{C}$ and $75 \%$ relative humidity as $3.3 \times 10^{-4} \mathrm{mg} \mathrm{U} / \mathrm{cm}^{2}-\mathrm{h}$ (Loewenstein 1980). Under such conditions, the addition of $0.75 \% \mathrm{Ti}$ to $\mathrm{U}$ metal appears to slow the oxidation rate by a factor of approximately 16 .

TABLE 2. Atmospheric 0xidation Rates of U Metal

\begin{tabular}{|c|c|c|c|}
\hline System & $\operatorname{Temp}\left({ }^{\circ} \mathrm{C}\right)$ & Rate Law & $\begin{array}{l}\text { Rate at } 25^{\circ} \mathrm{C} \\
\left(\mathrm{mg} / \mathrm{cm}^{2}-\mathrm{h}\right) \\
\end{array}$ \\
\hline U-dry air & $40 \leq \mathrm{T} \leq 300$ & $\left(6.9 \times 10^{8}\right) \exp (-18,300 / R T)$ & $2.6 \times 10^{-5}$ \\
\hline $\begin{array}{c}\text { U-water vapor } \\
(100 \% \mathrm{RH})\end{array}$ & $20 \leq T \leq 100$ & $\left(3.2 \times 10^{8}\right) \exp (-13,800 / R T)$ & $2.4 \times 10^{-2}$ \\
\hline $\begin{array}{c}\text { U- } 0_{2} \text {-water vapor } \\
(100 \% \mathrm{RH})\end{array}$ & $25 \leq T \leq 100$ & $\left(4.6 \times 10^{9}\right) \exp (-17,800 / R T)$ & $4.1 \times 10^{-4}$ \\
\hline $\begin{array}{c}\mathrm{U}-\mathrm{O}_{2} \text {-water vapor } \\
(2 \text { to } 90 \% \mathrm{RH})\end{array}$ & $40 \leq T \leq 130$ & $\left(4.8 \times 10^{13}\right) \exp (-25,000 / R T)$ & $2.2 \times 10^{-5}$ \\
\hline
\end{tabular}

For the rate laws, $T$ is temperature in degrees Kelvin, and $R$ is the gas constant in $\mathrm{cal} / \mathrm{mol} \cdot \mathrm{deg}$. 
These data $i l l u s t r a t e$ the importance of the presence of oxygen and relative humidity on the corrosion rate of $U$ metal. If the relative humidity is less than $90 \%$, the oxidation rate is significantly reduced to nearly that of water-free air. The effect of water vapor on the corrosion rate between 50 and $75^{\circ} \mathrm{C}$ has also been found to be small (Bennett and Price 1981). The higher oxidation rate in wet, oxygen-free environments is believed to be a result of the structural disruption of the metal caused by the formation of uranium hydride, which in turn is a result of the absorption and reaction of hydrogen that is produced by the reaction that exposes additional surface. In the presence of oxygen, the oxide film formed is more protective and the base metal is not disrupted.

Using the data provided in the Tables 1 and 2, the availability of U(IV) can be calculated using the mass of $U$ metal oxidized to $\mathrm{UO}_{2}$ per unit time. For example, if 1000 pieces from a $1-\mathrm{kg}$ disrupted penetrator average $1 \mathrm{~g}$ each in mass (Table 1 ), and if the reaction rate in the presence of $0_{2}$ and water vapor at $100 \%$ relative humidity is appropriate $\left(0.00041 \mathrm{mg} \mathrm{U} / \mathrm{cm}^{2}-\mathrm{h}\right.$; Table 2), then $0.28 \mathrm{mg}$ of $U$ metal will be oxidized each hour. The estimated lifetime of $1 \mathrm{~kg}$ of $U$ metal under these conditions will be about 410 years. In making that estimate, it is assumed that the surface of the metal is uniformly exposed in a humid air environment and that atmospheric oxidation dominates. For an intact DU penetrator having a mass of $1.345 \mathrm{~kg}, 0.075 \mathrm{mg}$ of $U$ metal would be oxidized to $\mathrm{UO}_{2}$ each hour, and the estimated lifetime of the penetrator would be around 2100 years. In either case, within a matter of hours the amount of $\mathrm{UO}_{2}$ available to be leached by rainwater exceeds several milligrams. Under some environmental conditions, the solubility of $\mathrm{UO}_{2}$ in water is on the order of a few micrograms of $U$ per 1 iter of water. Therefore, the rate at which $U$ metal is oxidized to $U$ (IV) oxide probably does not limit the mobility of $U$ in the subsurface pathway.

\section{Aqueous Corrosion}

For aqueous conditions, such as might exist in surface-water pools or along a shoreline, corrosion rates tend to be higher than atmospheric oxidation rates. For instance, in contrast to the rates given for atmospheric reactions in Table 2, the corrosion rate of $U$ in $5 \% \mathrm{NaCl}$ solution was 
observed to be $27 \mathrm{mi} 7 \mathrm{~s} /$ year (mpy, or $0.15 \mathrm{mg} / \mathrm{cm}^{2}-\mathrm{hr}$ ) and that of $U-0.75 \% \mathrm{Ti}$ to be $9.1 \mathrm{mpy}$ or $0.05 \mathrm{mg} / \mathrm{cm}^{2}-\mathrm{hr}$ (McIntyre et a1. 1988). Crevice areas (which have low oxygen concentrations) promoted $U-0.75 \% \mathrm{Ti}$ corrosion to rates of 30 mpy. The presence of chloride is important because concentrations as low as $0.005 \mathrm{M}$ (178 ppm chloride) can destroy passivity and cause pitting (Levy et a1. 1973). Once pitting has begun, areas with low oxygen content and an acidic environment will develop and accelerate the corrosion rate.

The reaction products of $U$ metal in water are probably similar to the oxidation products in water vapor (equation 2), and hydrogen would be produced in the absence of oxygen. The corrosion resistance of metals can be measured as the electrode potential relative to the standard calomel electrode (SCE). Large negative potentials are associated with high corrosion rates. Table 3 lists the electrode potentials of various metals in deionized water and in a $\mathrm{NaCl}$ solution at $29^{\circ} \mathrm{C}$. Although $\mathrm{U}$ metal is anodic to AISI 4340 carbon steel in the $\mathrm{NaCl}$ solution, the net corrosion rate for the $U$ metal is lower ( $8 \mathrm{mpy}$ ), possibly because more adherent films have formed (McIntyre et a1. 1988). Aluminum is normal1y anodic to $\mathrm{U}-0.75 \% \mathrm{Ti}$ in chloride-free solutions, but in chloride solutions the potentials reverse. However, even in this case, the corrosion rate of the $U$ alloy is low, near 3 mpy (McIntyre et al. 1988).

TABLE 3. Electrode Potentials for Metals (in V) at $29^{\circ} \mathrm{C}$ (Briggs 1985)

$5.0 \% \mathrm{NaCl}$ at $\mathrm{pH} 6.8$

304 SS $\quad+0.234$

$\mathrm{Ag} \quad-0.084$

$\mathrm{Cu} \quad-0.276$

Sn $\quad-0.482$

4340 steel $\quad-0.678$

DU $\quad-0.768$

5083 A1 $\quad-0.770$

$\mathrm{U}-.75 \mathrm{Ti}$

$\mathrm{Zn}$

$-0.838$

$-1.050$
Deaerated, Distilled water at $\mathrm{pH} 5.8$

$\begin{array}{ll}\mathrm{Ag} & +0.126 \\ 304 \mathrm{SS} & +0.102 \\ \mathrm{Cu} & +0.070 \\ \mathrm{Sn} & -0.142 \\ \mathrm{DU} & -0.163 \\ \mathrm{U}-.75 \mathrm{Ti} & -0.206 \\ 4340 \text { steel } & -0.442 \\ \mathrm{Zn} & -0.658 \\ 5083 \mathrm{Al} & -0.820\end{array}$




\section{FACTORS AFFECTING SOURCE-TERM URANIUM CONCENTRATIONS}

Most published information about the occurrence and mobility of $U$ in the natural environment has focussed on the geochemical conditions of formation of uranium ore deposits, the adsorption and ion-exchange of uranium on soil minerals, and the aqueous solubilities of uranium minerals. The calculation of uranium concentrations resulting from either solubility equilibrium with any uranium solid or adsorption of uranium on soil minerals is dependent on the set of thermodynamic data used in the calculation. Langmuir $(1978 a, b)$ has critically reviewed the thermodynamic properties of dissolved $U$ and the mineral-solution equilibria relevant to the formation of $U$ ore deposits. Since 1978, more recent thermodynamic data have been re-evaluated and compiled, and alternative viewpoints relevant to the aqueous behavior of $U$ (IV) or U(VI) have been presented in other reviews by Krupka et al. $(1983,1985)$ and Tripathi (1984). Krupka et al. (1983, 1985) reviewed thermodynamic data for the aqueous behavior of $U($ IV) and $U(V I)$ and evaluated experimental data for the solubilities of some uranium minerals. A review of thermodynamic data for U(VI) was also discussed by Tripathi (1984) who used the data to model experimental measurements of the adsorption of $U(V I)$ on goethite.

Although the speciation scheme used by Langmuir $(1978 a, b)$ differs from the later reviews of the speciation behavior of $U(I V)$ and $U(V I)$, the field descriptions and calculations relevant to the occurrence of uranium in nature presented by Langmuir (1978a,b) are still useful as a guide to the possible weathering reactions that may occur between soil pore waters and corrosion products of spent DU penetrators. Therefore, much of the following discussion is based upon the calculations presented by Langmuir $(1978 \mathrm{a}, \mathrm{b})$. The reader should be aware, however, that the calculations shown in the subsequent section of the report may differ substantially if another speciation scheme for the aqueous behavior of uranium is used to calculate the mineral solubility equilibria.

Uranium occurs in solids and in groundwater in two primary oxidation states, $U(I V)$ and $U(V I)$. Redox conditions therefore determine the form of dissolved $U$ in groundwater and the type of $U$ solids formed. The chemical composition of soil pore waters also determines which $U$ solid will be 
thermodynamically stable and the source-term concentration of dissolved $U$, because dissolved uranium concentrations are affected by the presence of complexing ligands, such as $\mathrm{OH}^{-}, \mathrm{Cl}^{-}, \mathrm{CO}_{3}{ }^{2-}, \mathrm{PO}_{4}{ }^{3-}, \mathrm{F}^{-}, \mathrm{H}_{4} \mathrm{SiO}_{4}{ }^{\circ}, \mathrm{SO}_{4}{ }^{2-}$, and soil organic acids.

The stability of various $U$ solids and the resulting $U$ concentrations in groundwater have been described by Langmuir (1978a,b) in terms of mineral solubility equilibria. An assumption made here is that the source-term concentrations of $U$ are solubility-limited by the interactions of near-surface waters and $U$-oxide corrosion products of DU. A review of the solubilities of $U$ solids as a function of relevant geochemical parameters will provide information on the range of $U$ concentrations that can be expected from the leaching of the oxidation products of the weathering of DU penetrators.

The most common $U$ ore minerals in reduced environments are the $U$ (IV) minerals, which include uraninite $\left(\mathrm{UO}_{2}\right)$, coffinite $\left[\mathrm{U}\left(\mathrm{SiO}_{4}\right)_{1-\mathrm{X}}(\mathrm{OH})_{4 x}\right]$, and (in some ore deposits in Japan that contain a source of phosphate) ningyoite $\left[(\mathrm{U}, \mathrm{Ca}, \mathrm{Ce})_{2}\left(\mathrm{PO}_{4}\right)_{2} \cdot 1-2 \mathrm{H}_{2} \mathrm{O}\right]$ (Muto 1965). Uranium (IV) in solution exists as the uranous ion $\left(\mathrm{U}^{4+}\right)$ and is complexed in reduced groundwater mainly in the form of several hydrolysis species, sulfate, chloride, and phosphate, and it is complexed by fluoride at $\mathrm{pH}$ values less than 4 (Langmuir 1978a). Figure 1 shows the distribution of these species for typical groundwater ligand concentrations, as calculated by Langmuir (1978a). Uranium (IV) complexes involving chloride, sulfate, and phosphate are insignificant over the $\mathrm{pH}$ range shown. Between $\mathrm{pH}$ values of 5 and 8 , the important $U$ (IV) complexes include the $\mathrm{U}(\mathrm{OH})_{4}{ }^{\mathrm{O}}$ and $\mathrm{U}(\mathrm{OH})_{5}{ }^{-}$hydrolysis species. At a pH of less than 3 , the $U(I V)$ fluoride complexes are dominant.

As discussed in the previous section, one of the first products expected from oxidation of spent DU penetrators is $\mathrm{UO}_{2}$. Figure 2 shows the change in uranium concentrations versus $\mathrm{pH}$, calculated for the solubility of uraninite in water (Langmuir 1978a). In the range of $\mathrm{pH}$ values common to most reduced groundwaters ( $\mathrm{pH} 5$ to 8 ), the solubility of uraninite is very low and dissolved $U$ concentrations are generally below $0.1 \mathrm{ppb}$ (Figure 2). Figure 2 also shows the effect of fluoride complexation on uraninite solubility at low $\mathrm{pH}$ values. More recent review and recalculation of the thermodynamic data 


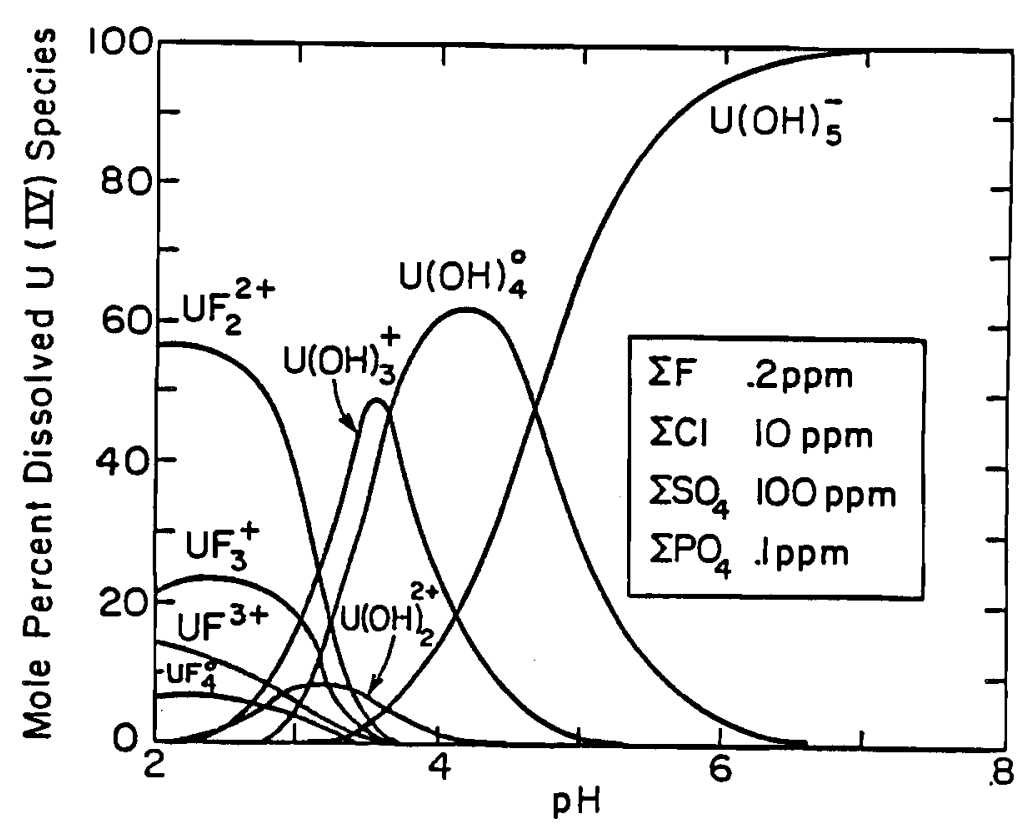

Figure 1. Distribution of the significant U(IV) complexes as a function of $\mathrm{pH}$ at $25^{\circ} \mathrm{C} \mathrm{calculated}$ for the ligand concentrations shown (Reprinted with permission, from Langmuir 1978a).

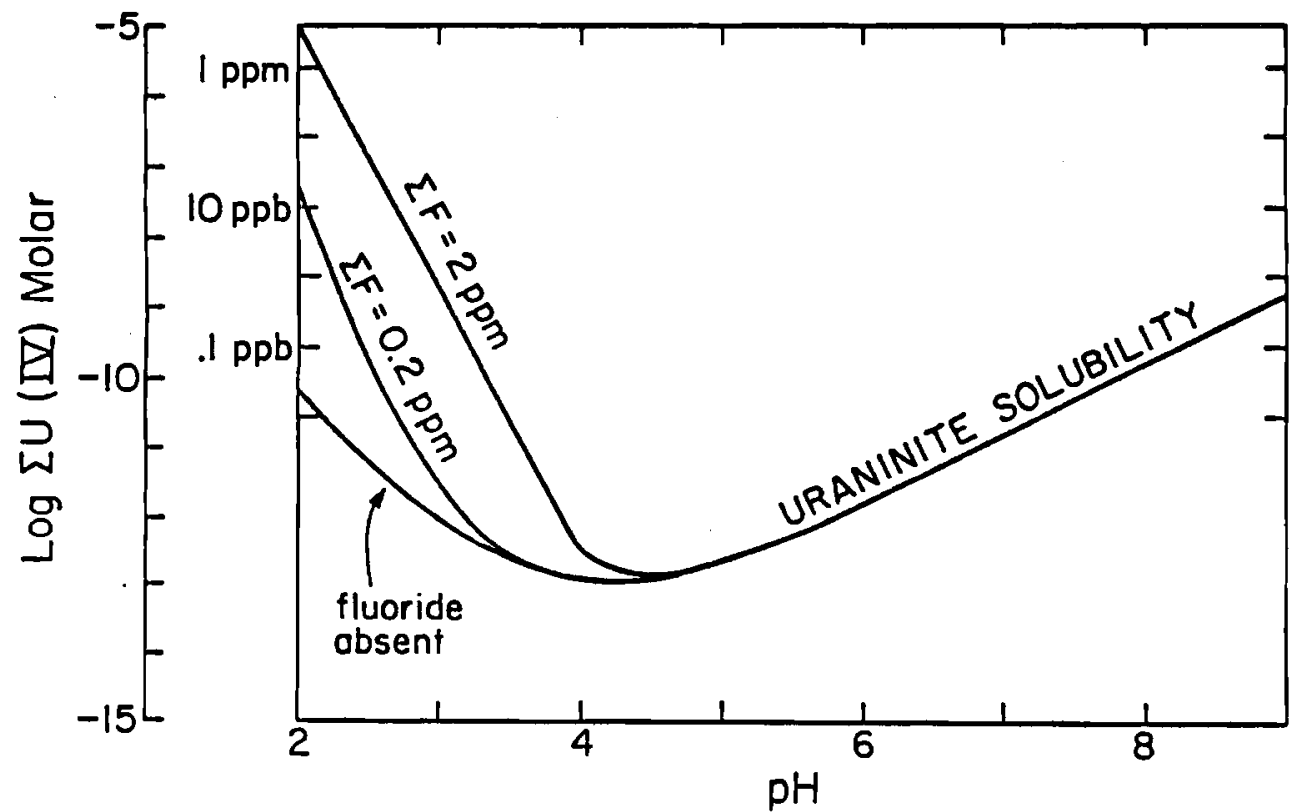

Figure 2. The solubility of uraninite $\left(\mathrm{UO}_{2}\right)$ as a function of $\mathrm{pH}$ at $25^{\circ} \mathrm{C}$, showing the effect of dissolved fluoride (Reprinted with permission, from Langmuir 1978a). 
involving $U$ (IV) aqueous species and calculations of uraninite solubility has shown that above $\mathrm{pH} 6$ the solubility of uraninite may be as much as two orders of magnitude smaller than that shown in Figure 2 (Krupka et al. 1983). Thus, in a reduced environment where $\mathrm{UO}_{2}$ is a stable solid, source-term concentrations of $U$ at typical groundwater $\mathrm{pH}$ values and ligand concentrations would be expected to be very small.

Because soil pore waters interacting with DU penetrators may be oxidizing, the stability of $\mathrm{UO}_{2}$ must be examined as a function of redox potential (Eh). In addition, the oxidation of $U$ to form $U(V I)$ oxides, their relative solubilities, and the aqueous complexation scheme for $U(V I)$ must also be reviewed. The oxidation of U(IV) to $U$ (VI) may modify the source-term concentrations and mobility of dissolved $U$ entering a soil profile, both because $U(V I)$ is strongly complexed by ligands commonly found in groundwater and because the solubilities of $U(V I)$ minerals are generally larger than that of $\mathrm{UO}_{2}$.

Dissolved $U(V I)$ exists in solution as the uranyl ion $\left(\mathrm{UO}_{2}{ }^{2+}\right)$, and forms complexes with $\mathrm{OH}-, \mathrm{CO}_{3}{ }^{2-}, \mathrm{F}^{-}, \mathrm{PO}_{4}{ }^{3-}, \mathrm{SO}_{4}{ }^{2-}$, and organic ligands. In Figure 3 , the distribution of the significant uranyl species calculated by Langmuir (1978a) is shown for ligand concentrations typical of the Wind River Formation (primarily sandstone units located in Wyoming). The uranyl ion is complexed primarily by fluoride at $\mathrm{pH}$ less than 4 , and it is strongly complexed by phosphate between $\mathrm{pH}$ values of 4 and 7.5. At higher $\mathrm{pH}$, dissolved uranium is present predominantly as the uranyl carbonate complexes shown in Figure 3. More recent work by Maya (1981) and Maya and Begun (1981) has shown evidence for additional hydroxocarbonato species that were not included in the calculations by Langmuir (1978a). The effects of the additional species on the $U$ (VI) speciation scheme and on the adsorption of $U$ (VI) were further evaluated by Tripathi (1984).

Both the proportion of the total dissolved $U$ that is divided into $U(I V)$ and $U(V I)$ aqueous complexes and the effect of the speciation scheme on the relative stabilities of the $U(I V)$ and $U(V I)$ minerals will depend on the Eh and the ligand concentrations in the soil pore water. Of the complexing ligands known to affect the concentrations of uranium in oxidized 


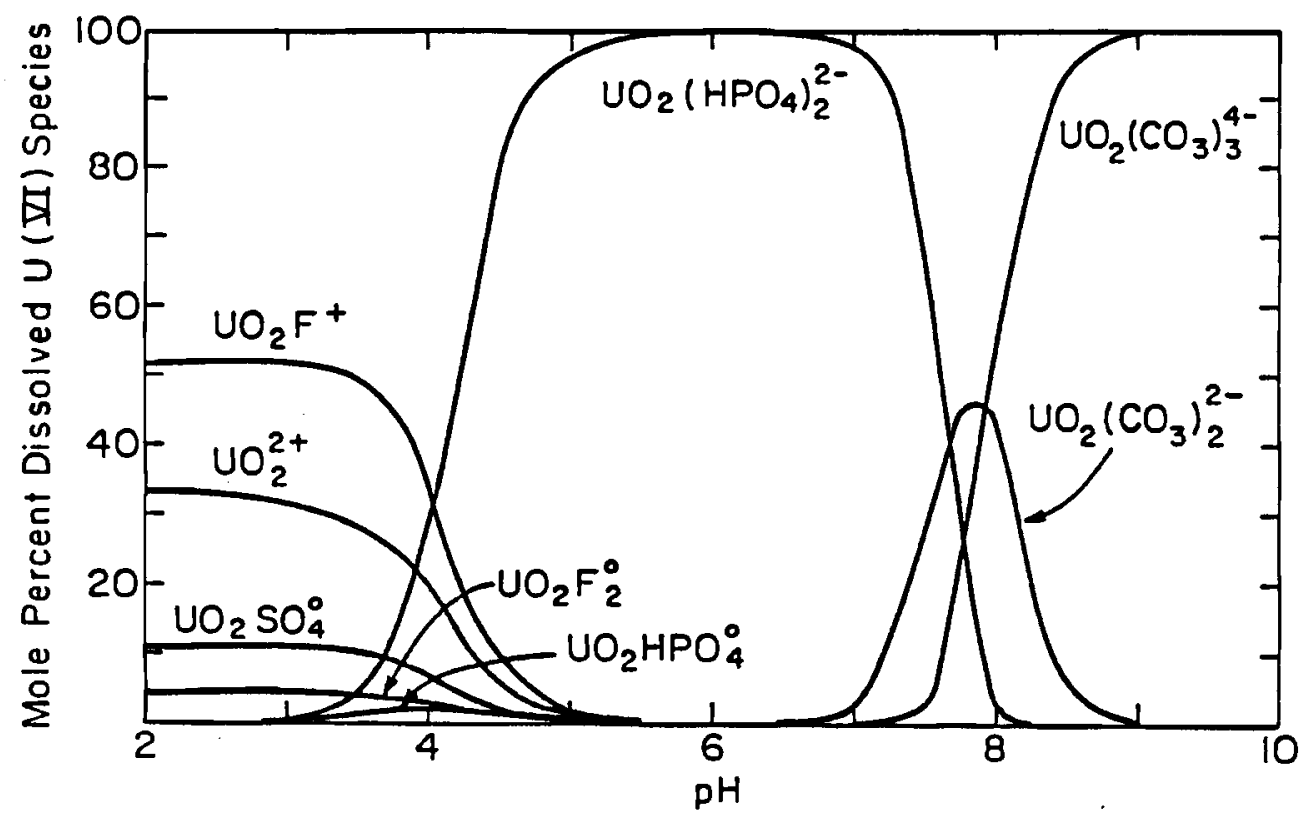

Figure 3. Distribution of significant $U(V I)$ complexes at $25^{\circ} \mathrm{C}$ as a function of $\mathrm{pH}$ for a groundwater having the following composition: $\mathrm{pCO}_{2}=10^{-2.5} \mathrm{~atm}, \mathrm{~F}=0.3 \mathrm{ppm}, \mathrm{Cl}=10 \mathrm{ppm}$, $\mathrm{SO}_{4}=100 \mathrm{ppm}, \mathrm{PO}_{4}=0.1 \mathrm{ppm}, \mathrm{SiO}_{2}=30 \mathrm{ppm}$ (Reprinted with permission, from Langmuir 1978a).

ground-water, dissolved carbonate and phosphate are considered the most important (Langmuir 1978a). The examples in Figures 4 through 6 illustrate some of the effects that the Eh and complexing ligands have on dissolved $U$ concentrations involving $\mathrm{UO}_{2}$ solubility.

Figure 4 is an Eh-pH diagram showing the stability fields for uraninite and for the dominant $U(I V)$ and $U(V I)$ aqueous species at a $\mathrm{CO}_{2}$ partial pressure $\left(\mathrm{pCO}_{2}\right)$ of $10^{-2} \mathrm{~atm}$ (the atmosphere has a $\mathrm{pCO}_{2}$ of $10^{-3.5^{2}}$ atm) and a total $U$ concentration of $10^{-6} \mathrm{M}(0.24 \mathrm{ppm})$. The diagram shows the dominance of the uranyl carbonate species at $\mathrm{pH}$ values above 6 and that uraninite is stable up to Eh values of about $+100 \mathrm{mV}$ in the neutral $\mathrm{pH}$ range at this $U$ concentration. The effect of dissolved carbonate on $U$ concentrations resulting from the solubility of $\mathrm{UO}_{2}$ is shown in Figure 5 at a $\mathrm{pH}$ of 8 for two $\mathrm{CO}_{2}$ partial pressures. In more oxidized groundwater, the increase in $\mathrm{UO}_{2}$ solubility is a 


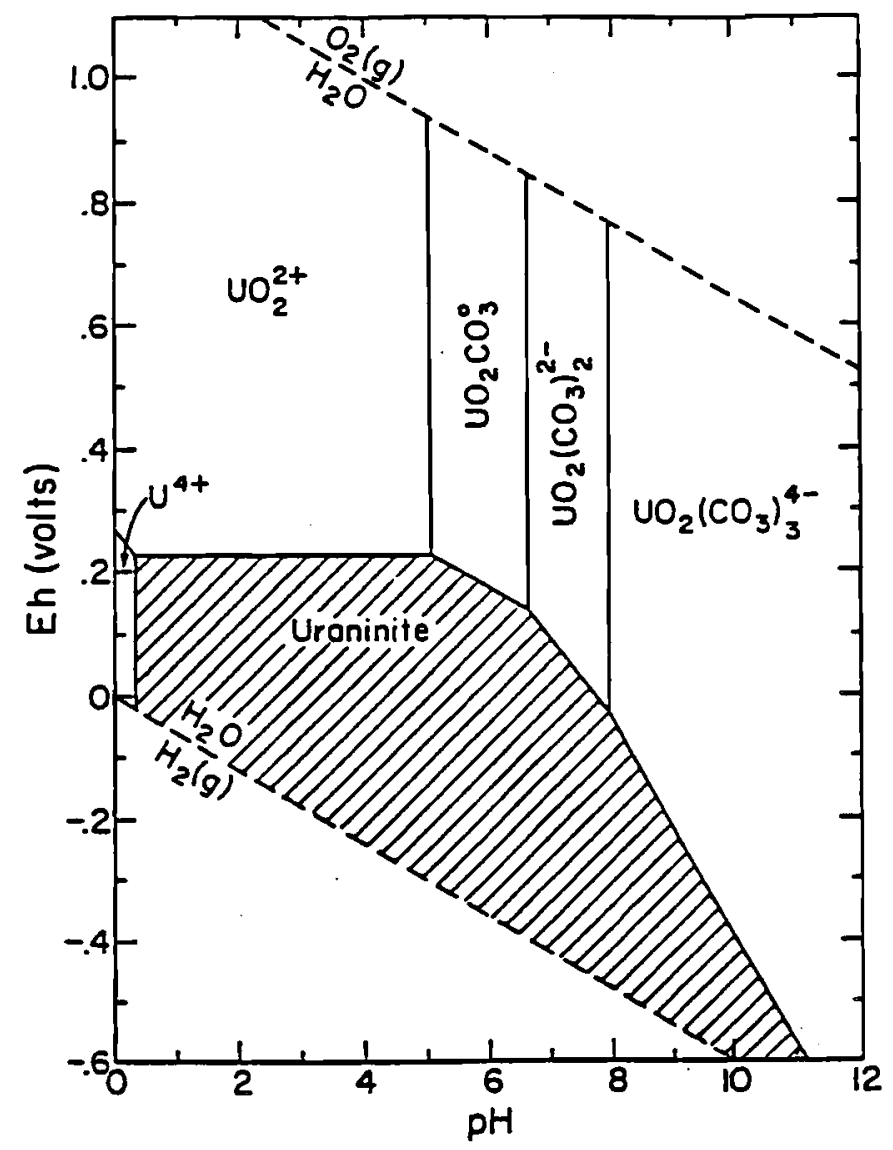

Figure 4. Eh-pH diagram in the system $\mathrm{U}-\mathrm{O}_{2}-\mathrm{CO}_{2}-\mathrm{H}_{2} \mathrm{O}$ at $25^{\circ} \mathrm{C}$, showing the stability field of $\mathrm{UO}_{2}$ for a total. $U$ concentration of $0.24 \mathrm{ppm}$ and a $\mathrm{pCO}_{2}$ of $0.01 \mathrm{~atm}$ (Reprinted with permission, from Langmuir 1978a).

result of the complexation of the uranyl ion by dissolved carbonate. At any Eh value above $-200 \mathrm{mV}$, an increase in $\mathrm{pCO}_{2}$ results in a larger uraninite solubility. A similar plot (Figure 6) for two phosphate concentrations shows the increase in uraninite solubility at high Eh values that occurs because of complexation of uranyl ion by phosphate. Therefore, source-term concentrations of $U$ resulting from $\mathrm{UO}_{2}$ solubility will depend on the $\mathrm{Eh}, \mathrm{pH}$, and concentration of complexing ligands in the near-surface waters. Typical surface waters in equilibrium with the atmosphere have Eh values between +250 and $+500 \mathrm{mV}$, suggesting $\mathrm{UO}_{2}$ is likely to be more soluble than $U(V I)$ minerals. Under these conditions, U(VI) minerals may be more stable and consequently may control aqueous $U$ concentrations at lower values. 


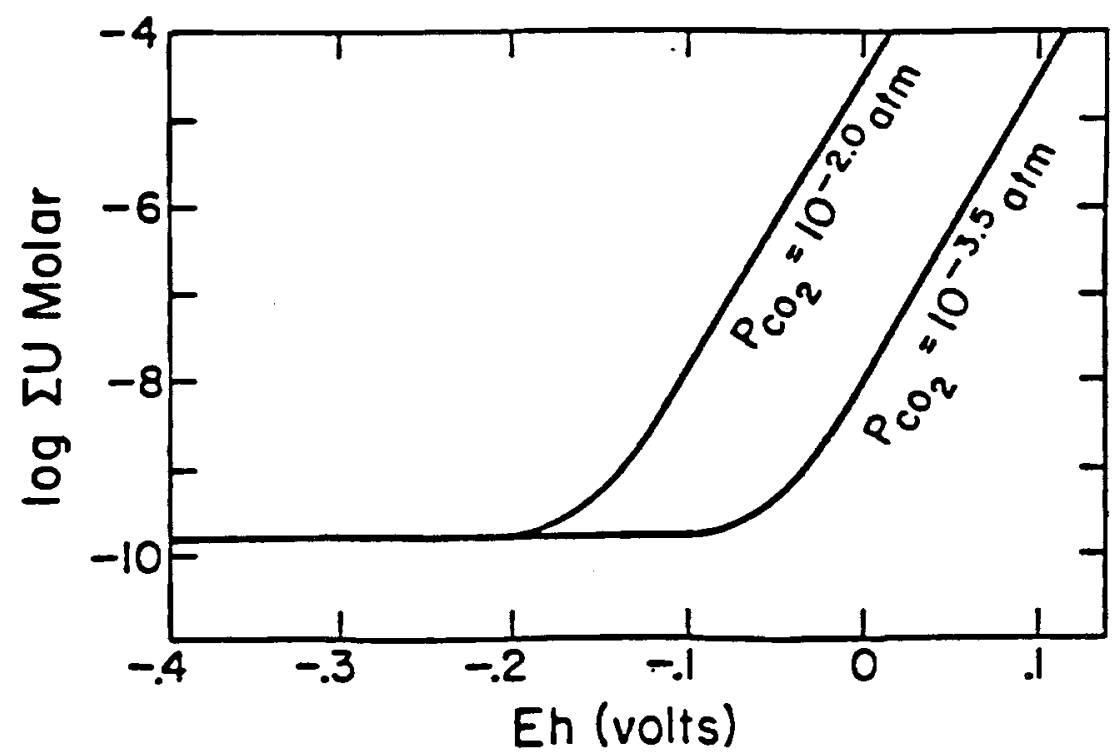

Figure 5. The solubility of $\mathrm{UO}_{2}$ at $25^{\circ} \mathrm{C}$ and $\mathrm{pH} 8$ as a function of Eh and $\mathrm{pCO}_{2}$ (Reprinted with permission, from Langmuir 1978a).

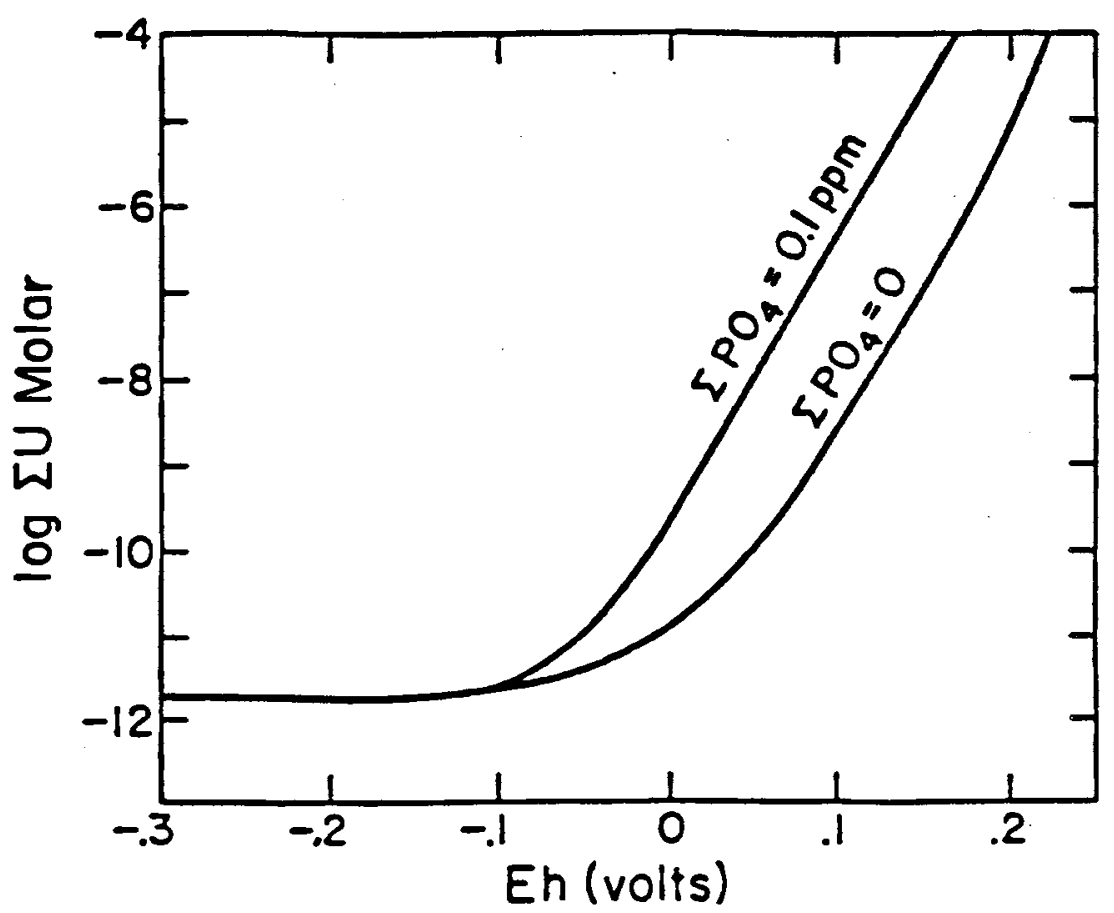

Figure 6. The solubility of $\mathrm{UO}_{2}$ at $\mathrm{pH} 6, \mathrm{pCO}_{2}=0.01$ atm, and $25^{\circ} \mathrm{C}$ for two phosphate concentrations (Reprinted with permission, from Langmuir 1978a). 


\section{ATTENUATION BEHAVIOR OF URANIUM}

Other reactions between local soils and groundwater may also affect the concentrations of $U$ transported through a soil profile. These reactions include precipitation of secondary $U$ minerals, ion exchange of $U$ on clay minerals, and specific-ion adsorption of $U$ on mineral surfaces. All three types of mass-transfer reactions could decrease the concentration of $U$ in groundwater migrating through a soil profile.

The precipitation of U(VI) minerals from an oxidized groundwater containing uranium that has been leached from corroded DU penetrators is one mechanism that could attenuate the subsurface migration of $U$. Which $U$ (VI) minerals precipitate will depend on the $\mathrm{pH}$ and ligand concentrations in the groundwater. Some of the more common U(VI) minerals found in oxidized zones near uranium ore deposits are carnotite $\left[\mathrm{K}_{2}\left(\mathrm{UO}_{2}\right)_{2}\left(\mathrm{VO}_{4}\right)_{2} \cdot 3 \mathrm{H}_{2} \mathrm{O}\right]$, tyuyamunite $\left[\mathrm{Ca}\left(\mathrm{UO}_{2}\right)_{2}\left(\mathrm{VO}_{4}\right)_{2} \cdot 2 \cdot 5-8 \mathrm{H}_{2} \mathrm{O}\right]$, autunite $\left[\mathrm{Ca}\left(\mathrm{UO}_{2}\right)_{2}\left(\mathrm{PO}_{4}\right)_{2} \cdot 10-12 \mathrm{H}_{2} \mathrm{O}\right]$, and uranophane [Ca $\left.\left(\mathrm{UO}_{2}\right)_{2} \mathrm{Si}_{2} \mathrm{O}_{7} \cdot 6 \mathrm{H}_{2} \mathrm{O}\right]$ (Langmuir 1978a). Of these $\mathrm{U}(\mathrm{VI})$ minerals, carnotite and tyuyamunite are the least soluble in groundwater containing small quantities of dissolved vanadium. Figures 7 and 8 show the solubilities of carnotite and tyuyamunite as a function of $\mathrm{pH}$, as calculated by Langmuir (1978a). In the $\mathrm{pH}$ range from 5 to 8 , either solid could limit the total concentration of dissolved $U$ to levels less than $10^{-8}$ molar $(\sim 2 \mathrm{ppb} U)$ at atmospheric $\mathrm{pCO}_{2}\left(10^{-3.5} \mathrm{~atm}\right)$. The uppermost curves in Figures 7 and 8 show the effect of increasing the partial pressure of $\mathrm{CO}_{2}$ gas. The higher solubility at any $\mathrm{pH}$ value illustrates the effect of complexation of the uranyl ion by dissolved carbonate.

For groundwater that does not contain vanadium but does contain dissolved phosphate, autunite is the least soluble $U$ (VI) mineral that could limit the concentration of $U$ (Langmuir 1978a). Figure 9 shows the solubility of autunite as a function of $\mathrm{pH}$ and $\mathrm{pCO}_{2}$. In the $\mathrm{pH}$ range shown at either of the $\mathrm{pCO}_{2}$ values, autunite is more soluble than the uranyl vanadate minerals (Figures 7 and 8 ). The mineral uranophane is more soluble than any of the uranyl vanadate or phosphate minerals discussed above at the vanadium and 


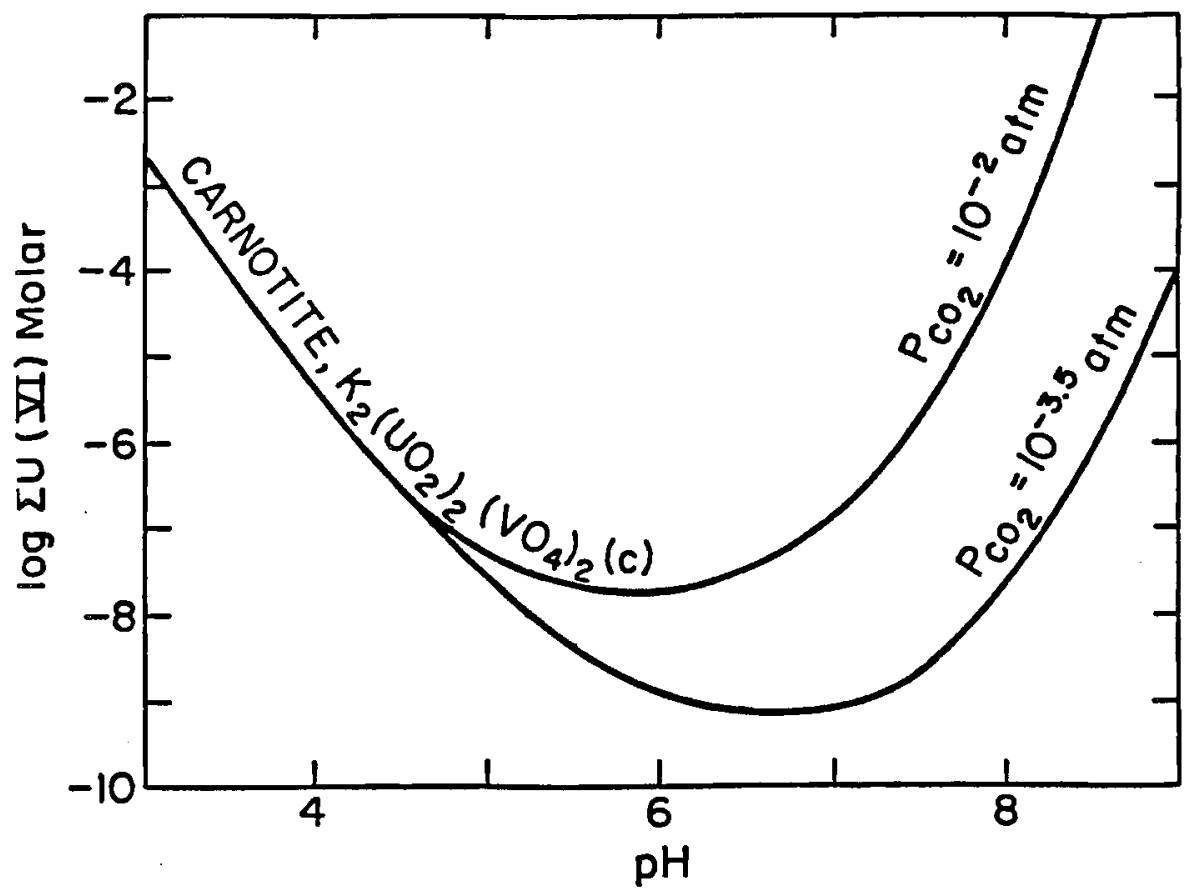

Figure 7. The solubility of carnotite at $25^{\circ} \mathrm{C}$ as a function of $\mathrm{pH}$ and $\mathrm{pCO}_{2}$ for concentrations of $\mathrm{K}=39 \mathrm{ppm}$ and $\mathrm{VO}_{4}=0.1 \mathrm{ppm}$ (Reprinted with permission, from Langmuir 1978a).

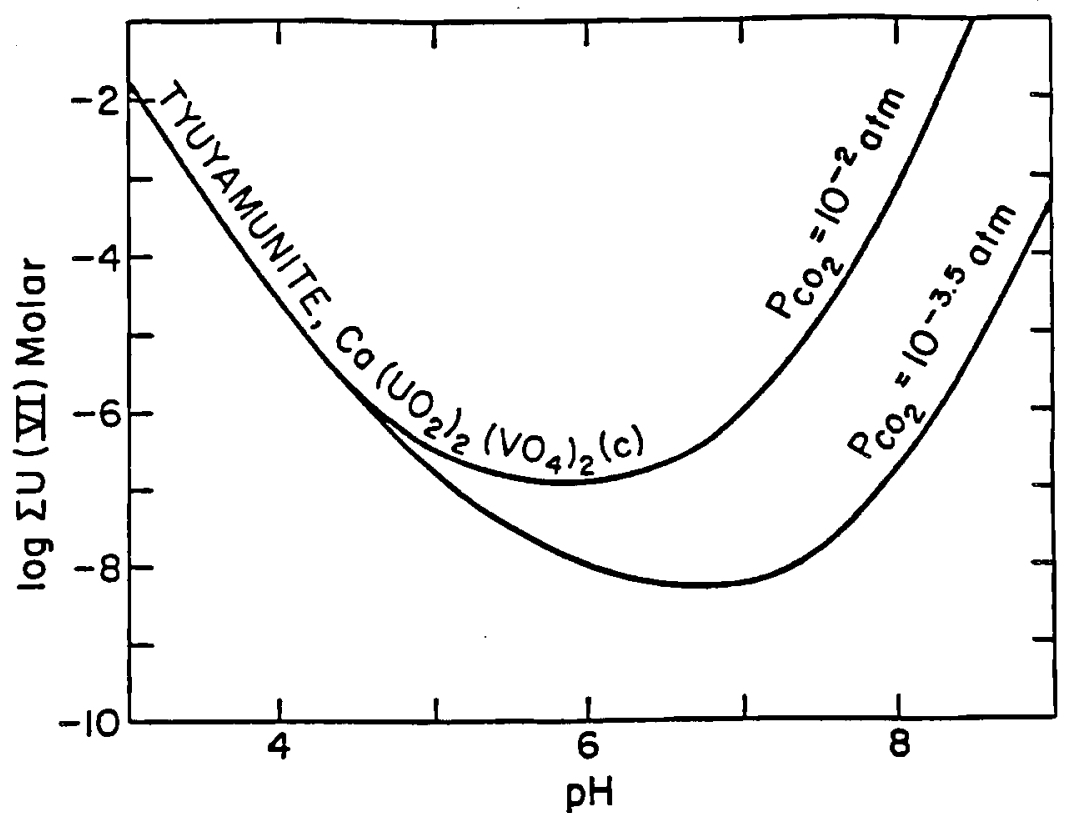

Figure 8. The solubility of tyuyamunite at $25^{\circ} \mathrm{C}$ as a function of $\mathrm{pH}$ and $\mathrm{pCO}_{2}$ for concentrations of $\mathrm{Ca}=80 \mathrm{ppm}$ and $\mathrm{VO}_{4}=0.1 \mathrm{ppm}$ (Reprinted with permission, from Langmuir 1978a). 


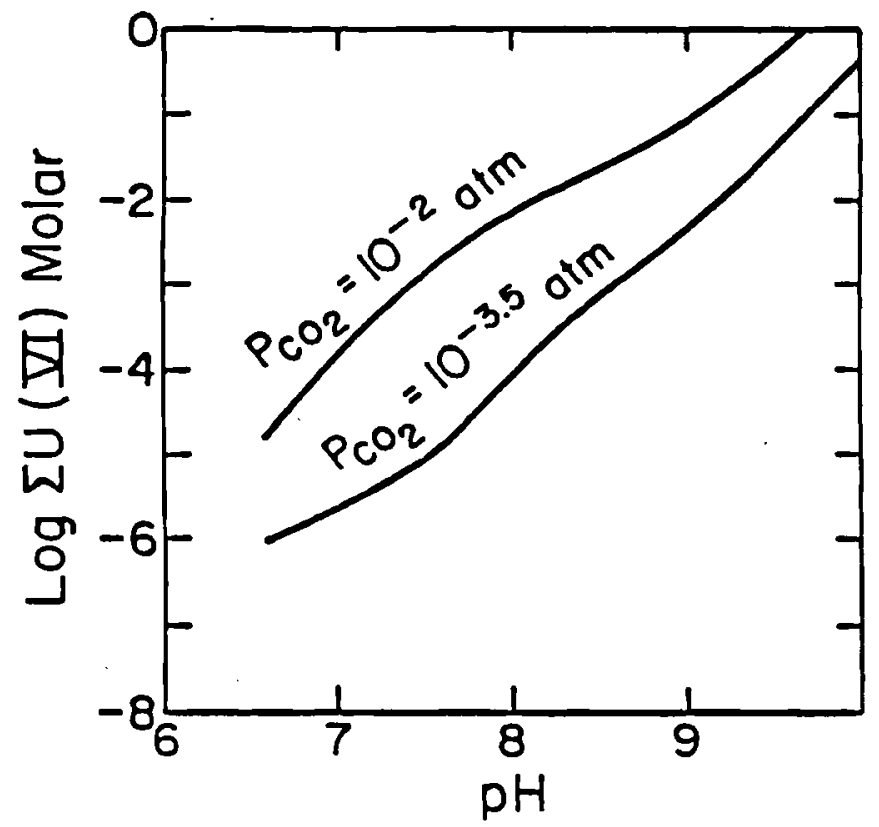

Figure 9. The solubility of autunite at $25^{\circ} \mathrm{C}$ as a function of $\mathrm{pH}$ and $\mathrm{pCO}_{2}$ for concentrations of $\mathrm{Ca}=80 \mathrm{ppm}$ and $\mathrm{PO}_{4}=0.1 \mathrm{ppm}$ (Reprinted with permission, from Langmuir 1978a).

phosphorus concentrations expected in groundwater (Langmuir 1978a). Therefore, if groundwater source-term concentrations of $U$ leached from DU penetrators enter a soil profile above the solubility limits of the $U$ (VI) minerals, precipitation of the $U(V I)$ minerals could lower the concentration of dissolved $U$. The relative stabilities of these minerals will depend primarily on the concentrations of dissolved vanadate and phosphate in the groundwater. The solubility-limited concentration of $U$ transported through the soil profile will also depend on the groundwater $\mathrm{pH}$, Eh, and carbonate concentration.

A second mechanism that can attenuate the transport of $U$ through sediments is the adsorption of dissolved $U$ on mineral surfaces, by either ion exchange or specific adsorption reactions. The adsorption of the uranyl ion has been studied experimentally on a variety of surfaces including organic matter (peat), clay minerals, and ferric oxides and oxyhydroxides that are common in soils. 
In their description of the mineralization of $U$ ore deposits in Japan, Doi et al. (1975) suggested that adsorption of $U$ on organic matter was the most important factor in concentrating $U$ on solid surfaces. Doi et al. (1975) reported that in suspensions of $1 \mathrm{~g}$ of peat per $100 \mathrm{ml}$ uranyl perchloride acid solution ( $4 \mathrm{ppm} \mathrm{U}$ ) between $\mathrm{pH}$ values of 3 and 8.5 up to $100 \%$

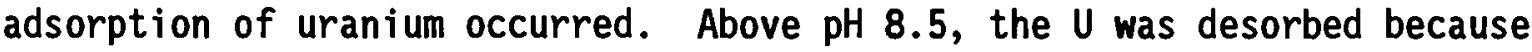
$\mathrm{NaHCO}_{3}$ was used to adjust the $\mathrm{pH}$ of the solutions, resulting in increased carbonate complexation of the uranyl ion.

Several experimental studies have measured the affinity of the uranyl ion for different clay mineral surfaces commonly found in soils. Borovec (1981) measured the distribution coefficients (Kd) of $U$ on kaolinite, illite, and montmorillonite in chloride solutions containing between $10^{-2}$ and $10^{-5}$ molar (2400-2 ppm) U(VI) at pH 6. For dissolved $U$ concentrations less than $10^{-4}$ molar, the $\mathrm{Kd}$ values measured increased from 50 to about $1000 \mathrm{ml} / \mathrm{g}$ in the order kaolinite < illite < montmorillonite. Ames et al. (1983a) performed similar measurements for the same clay minerals at $\mathrm{pH} 7$ in $\mathrm{NaCl}$ solutions and $\mathrm{pH}$ 8-9 in $\mathrm{NaHCO}_{3}$ solutions. Maximum $\mathrm{Kd}$ values in the $\mathrm{NaCl}$ solutions for illite, montmorillonite, and kaolinite were 500, 650, and $700 \mathrm{ml} / \mathrm{g}$, respectively. In the carbonate solutions, the cation exchange of uranyl ion on the clays was reduced because aqueous complexation reactions formed uranyl carbonate species. As a result, the maximum Kds for illite and montmorillonite decreased to 110 and 2, respectively. This pattern is consistent with the decreased affinity of clay mineral surfaces for the uranyl ion. Similar measurements were made by Ames et al. (1983b) for several mica minerals (biotite, phlogopite, muscovite) that are less prominent in weathered soils.

Perhaps the most important soil mineral surfaces with a strong affinity for adsorbing dissolved solutes are the surfaces of iron oxides and oxyhydroxides. Ames et al. (1983c) measured the adsorption of uranyl ion on amorphous ferric hydroxide in $\mathrm{NaCl}$ solution at $\mathrm{pH} 7$ and in $\mathrm{NaHCO}_{3}$ solution at $\mathrm{pH}$ 8.7. Calculations from the measurements suggest that the $\mathrm{Kd}$ for $\mathrm{U}(\mathrm{VI})$ is greater than $2 \times 10^{6} \mathrm{ml} / \mathrm{g}$ in $\mathrm{NaCl}$ solution and $3 \times 10^{4} \mathrm{ml} / \mathrm{g}$ in $\mathrm{NaHCO}_{3}$ solution. More comprehensive studies of uranyl adsorption by iron oxides and oxyhydroxides have since been published by Hsi and Langmuir (1985) and by 
Tripathi (1984). These studies discuss the adsorption of U(VI) over a wider range of $\mathrm{pH}$ values with and without dissolved carbonate present. For example, Hsi and Langmuir (1985) showed that uranyl ion is strongly adsorbed by hematite, goethite, and amorphous ferric oxyhydroxide at $\mathrm{pH}$ values greater than 5 to 6 (Figure 10). Adsorption was greatest on the amorphous
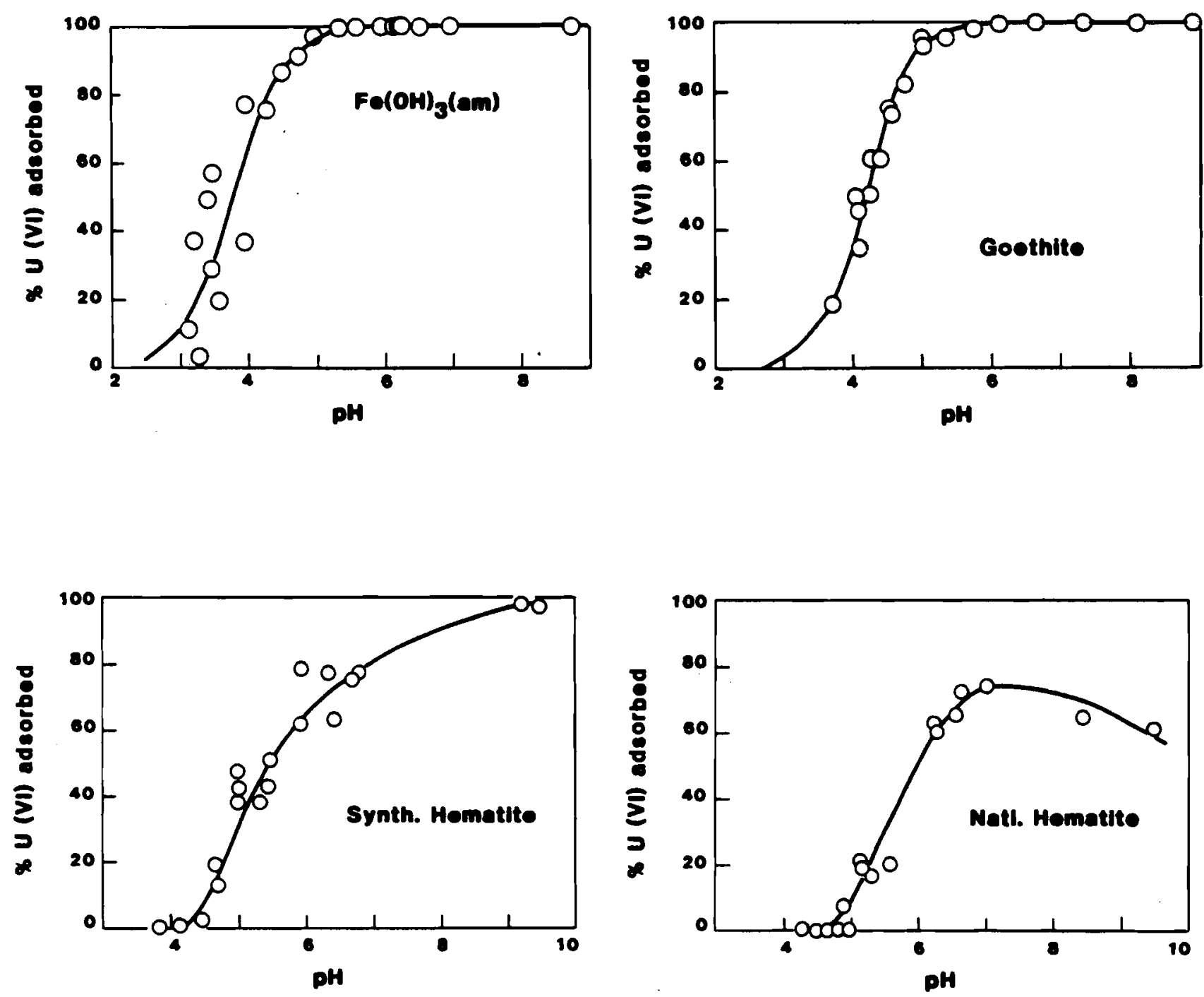

Figure 10. Adsorption of uranyl $1_{5}$ ion versus $\mathrm{pH}$ at a total $\mathrm{U}$ concentration of $10^{-5} \mathrm{molar}(2.4 \mathrm{ppm})$ onto $1 \mathrm{~g} / \mathrm{L}$ suspensions of ferric oxyhydroxides in

$0.1 \mathrm{M} \mathrm{NaNO}_{3}$ solutions at $25^{\circ} \mathrm{C}$ (Reprinted with permission, from Hsi and Langmuir (1985). 
oxyhydroxide and least on hematite. At total $U$ concentrations of $10^{-5} \mathrm{molar}$ (2.4 ppm), essentially all U(VI) is adsorbed by $1 \mathrm{~g} / \mathrm{L}$ of goethite and amorphous ferric oxyhydroxide above $\mathrm{pH} 5$ in the carbonate-free system. Hematite adsorbed only about $80 \%$ of the $U$ over the same $\mathrm{pH}$ range. In the presence of dissolved carbonate at concentrations of $10^{-3}$ to $10^{-2} \mathrm{~mol}$ ar (60-600 ppm), $U$ adsorption was inhibited on all of the ferric oxide surfaces above pH 6.5.

The results of the adsorption studies of dissolved $U$ on common mineral surfaces show that the iron oxides and oxyhydroxides have the strongest affinity for $U(V I)$ adsorption. The affinity of these surfaces for the uranyl ion could reduce the concentrations of dissolved $U$ in groundwater and thus attenuate its subsurface transport. The data al so show that dissolved carbonate present at concentrations common in most groundwater could inhibit the attenuation of dissolved uranium because of complexation effects. As a result, an accurate assessment of the potential for the attenuation of the subsurface transport of uranium requires site-specific field characterization data relevant to the groundwater chemistry and to the types and quantities of minerals present in local subsurface soils.

\section{UPTAKE OF URANIUM BY PLANTS}

The uptake of radionuclides by $\mathrm{plants}$ from soils has been modeled using element-specific $\mathrm{plant/soil} \mathrm{concentration} \mathrm{ratios} \mathrm{(CR).} \mathrm{In} \mathrm{a} \mathrm{review} \mathrm{of} C R$ values for $U$, Th, and $\mathrm{Pb}$, Sheppard and Evenden (1988) recommended appropriate values for $U$ to be used in environmental assessments. The mobility of $U$ in the soil is an important factor governing the uptake by plants and is dependent on $U$ solution species and on the particle size of the soil, which affects the soil adsorption/retention characteristics. The mobility of $U$ is increased through complexation with the carbonate anion and, in some cases, by soil organic matter. It was suggested by Sheppard and Evenden (1988) that the uptake of radionuclides by $\mathrm{plants}$ is correlated with radionuclide concentrations in the soil pore waters more strongly than with total concentrations in the soil. Existing CR data for radionuclides have limited application because such ancillary data as the soil pH and concentrations of organic and carbonate ligands are usually not reported (Sheppard and Evenden 1988). It 
is therefore difficult to interpret and categorize the CR data based on the chemical composition of the soils and soil pore waters. These same limitations also apply to the environmental sampling data discussed above for the LASL site and for the ranges on the Aberdeen Proving Grounds.

\section{CONCLUSIONS}

The results of this review suggest there is a potential for $U$ from spent DU penetrators that is dispersed in soils to become mobilized and travel through the groundwater and surface water pathways. The oxidation of $U$ metal to $U$ (IV) oxide probably will not 1 imit the mobility of $U$ in the surface or subsurface water pathways. The potential for $U$ migration depends on the oxidation products of the depleted $U$ and on the chemistry of local soils and pore waters. Uranium (VI) is more mobile than U(IV) because of complexation reactions involving ligands commonly found in natural waters; carbonate and phosphate are generally considered the most important of these. The mobility of $U$ in the environment therefore depends on $\mathrm{Eh}, \mathrm{pH}$, and the presence of complexing ligands. The transport of $U$ may also be affected by attenuation reactions that could reduce $U$ concentrations in local groundwater and surface water. These reactions include ion exchange and specific adsorption of $U$ on organic matter, clay minerals, and ferric oxides and oxyhydroxides commoniy present in soils.

Evaluating the potential for $U$ migration and uptake from spent DU penetrators at a particular location requires detailed field characterization data for the chemical composition of surface water, and groundwater, and soil. We have shown that the concentrations of $U$ to be expected in groundwater are strongly dependent on the chemical compositions of both the groundwater and local soils. The results of Sheppard and Evenden (1988) suggest that these same factors are also important to the uptake of $U$ by $\mathrm{plants.} \mathrm{Because} \mathrm{concentrations} \mathrm{of} \mathrm{total} U$ in contaminated soils and groundwater were the only chemical measurements reported for the LASL and Aberdeen target ranges, it was not possible to develop a quantitative understanding of the differences between the measured $U$ concentrations in the local groundwater at these sites. 
Interpretation of aqueous and soil $U$ concentrations in terms of specific geochemical mechanisms is not possible without supporting data. It is not sufficient to report only $U$ concentrations in surface water, groundwater, or soils. To develop an understanding of the processes controlling the corrosion rate and the subsequent $U$ migration requires additional measurements. Measurements for surface and pore waters should (at a minimum) include $\mathrm{pH}$, Eh, and the concentrations of major cations, anions, specific trace elements (e.g., $V$ and $P$ ), and dissolved organic compounds. The soils should be characterized for mineral type and content, organic matter, and amorphous iron hydroxide contents. Further site-specific soil experiments should be performed to quantify $U$ attenuation.

\section{REFERENCES}

Ames L. L., J. E. McGarrah, and B. A. Walker. 1983a. "Sorption of Trace Constituents from Aqueous Solutions onto Secondary Minerals. I. Uranium." Clays and Clay Minerals 31:321-334.

Ames L. L., J. E. McGarrah, and B. A. Walker. 1983b. "Sorption of Uranium and Radium by Biotite, Muscovite, and Phlogopite." Clays and Clay Minerals $31: 343-351$.

Ames L. L., J. E. McGarrah, B. A. Walker, and P. F. Salter. 1983c. "Uranium and Radium Sorption on Amorphous Ferric Oxyhydroxide." Chemical Geology $40: 135-148$.

Aronson S., R. B. Roof, Jr., and J. Belle. 1957. "Kinetic Study of the Oxidation of Uranium Dioxide." Journal of Chemical Physics 27:137-144.

Bennett, M. J., and J. B. Price. 1981. "The Oxidation Behaviour of Uranium in Air at 348-765 K." Journal of Nuclear Materials 101:44-45.

Bloch J., U. Atzmony, M. P. Dariel, M. H. Mintz, and N. Shamir. 1982. "Surface Spectroscopy Studies of the Oxidation Behavior of Uranium." Journal of Nuclear Materials 105:196-200.

Borovec, Z. 1981. "The Adsorption of Uranyl Species by Fine Clay." Chemical Geology 32:45-58.

Briggs, J. L. 1985. The Corrosion Resistance of Zinc Coatings on Depleted Uranium and Uranium Alloys. RFP-3651, Rockwe11 International, Golden, Colorado.

Doi K., S. Hirono, and Y. Sakamaki. 1975. "Uranium Mineralization by Ground Water in Sedimentary Rocks, Japan." Economic Geology 70:628-646. 
Hanson, W. C. 1974. Ecological Considerations of Depleted Uranium Munitions. LA-5559, Los Alamos Scientific Laboratory, Los Alamos, New Mexico.

Hanson, W. C., and F. R. Miera, Jr. 1976. Long-Term Ecological Effects of Exposure to Uranium. LA-6269, Los Alamos Scientific Laboratory, Los A1amos, New Mexico.

Hanson, W. C., and F. R. Miera, Jr. 1977. Continued Studies of Lonq-Term Ecological Effects of Exposure to Uranium. LA-6742, Los Alamos Scientific Laboratory, Los Alamos, New Mexico.

Hsi, C-K. D., and D. Langmuir. 1985. "Adsorption of Uranyl onto Ferric Oxyhydroxides: Application of the Surface Complexation Site-Binding Model." Geochimica et Cosmochimica Acta 49:1931-1941.

Krupka, K. M., E. A. Jenne, and W. J. Deutsch. 1983. Validation of the WATE04 Geochemical Model for Uranium. PNL-4333, Pacific Northwest Laboratory, Richland, Washington.

Krupka, K. M., D. Rai, R. W. Fulton, and R. G. Strickert. 1985. "Solubility Data for U(VI) Hydroxide and Np(IV) Hydrous 0xide: Application of MCC-3 Methodology." Materials Research Society Symposium Proceedings 44:753-760.

Langmuir, D. 1978a. "Uranium Solution-Mineral Equilibria at Low Temperatures with Applications to Sedimentary Ore Deposits." Geochimica et Cosmochimica Acta 42:547-569.

Langmuir, D. 1978b. "Uranium Solution-Mineral Equilibria at Low Temperatures with Applications to Sedimentary Ore Deposits." In Uranium Deposits, Their Mineralogy and Origin, pp. 17-56. Mineralogical Association of Canada, Short Course Handbook 3, University of Toronto Press, Toronto, Canada.

Levy, M., C. V. Zabielski, and G. N. Sklover. 1973. Corrosion Behavior of Depleted Uranium-Titanium and Uranium-Molybdenum Alloys. AMMRC TR 73-11, Army Materials and Mechanics Research Center, Watertown, Massachusetts.

Loewenstein, P. 1980. "Industrial Uses of Depleted Uranium." In Properties and Selections: Stainless Steels, Tool Materials, and Special Purpose Metals, Metals Handbook, 9th ed., Vol. 3, pp. 778-779. American Society of Metals.

Maya, L. 1981. "Hydrolys is and Carbonate Complexation of Dioxouranium (VI) in the Neutral-pH Range at $25^{\circ} \mathrm{C}$." Inorganic Chemistry 21:2895-2898.

Maya, L., and G. M. Begun. 1981. "A Raman Spectroscopy Study of Hydroxo and Carbonato Species of the Uranyl(VI) Ion." Journal of Inorganic Nuclear Chemistry 43:2827-2832. 
McIntyre, J. F., E. P. Lefeave, and K. A. Musselman. 1988. "Galvanic Corrosion Behavior of Depleted Uranium in Synthetic Seawater Coupled to Aluminum, Magnesium, and Mild Steel." Corrosion-NACE 44(8):502-510.

Muto, T. 1965. "Thermochemical Stability of Ningyoite." Mineralogic Journal 4:245-274.

Ritchie, A. G. 1981. "A Review of the Rates of Reaction of Uranium with Oxygen and Water Vapour at Temperatures up to $300^{\circ} \mathrm{C}$." Journal of Nuclear Materials 102:170-182.

Robie, R. A., B. S. Hemingway, and J. R. Fisher. 1978. Thermodynamic Properties of Minerals and Related Substances at 298.15K and I Bar Pressure and at Higher Temperatures. United. States Geological Survey Bulletin 1452, U.S. Geological Survey, Washington, D. C.

Sheppard, S. C., and W. G. Evenden. 1988. "Critical Compilation and Review of Plant/Soil Concentration Ratios for Uranium, Thorium, and Lead." Journal of Environmental Radioactivity 8:255-285.

Stoetze1, G. A., D. A. Waite, and R. L. Gilchrist. 1983. Environmental Survey of the B-3 and Ford's Farm Ranges. PNL-2976, Pacific Northwest Laboratory, Richland, Washington.

Tripathi, V. S. 1984. Uranium (VI) Transport Modeling: Geochemical Data and Submodels. Ph.D. Dissertation, Stanford University, Stanford, California.

Tyzack, C., and H. C. Cowen. 1976. "The Corrosion of Reactor Materials in Carbon Dioxide." Atomic Energy Review 14:263-324. 

PNL -7213

UC -602

\section{DISTRIBUTION}

No. of

Copies

OFF-POST

2 DOE/Office of Scientific and Technical Information

C. Reynolds

Los Alamos Scientific Laboratory

Mail Stop J-495

Los Alamos, New Mexico 87545

ON-POST

25 Combat Systems Test Activity

D. M. Nett

STECS-SO-S/Safety office

Building 324

Aberdeen Proving Ground

Aberdeen, MD 21005-5059
No. of

Copies

22 Pacific Northwest Laboratory

J. R. Divine

R. L. Erikson

C. J. Hostetler

J. Mishima

L. H. Munson

M. A. Parkhurst

K. R. Price (9)

J. R. Raymond

R. J. Serne

Technical Report Files (5) 